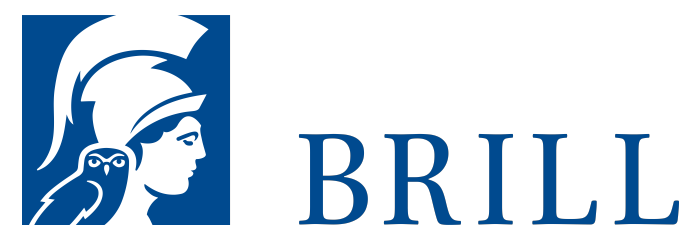

\title{
Das aufgehobene Bild
}

Collage als Modus der Malerei von Pablo Picasso bis Richard Prince

Authors: Petrus Graf von Schaesberg and

Petrus Graf von Schaesberg

Pablo Picasso, Kasimir Malewitsch, Kurt Schwitters, Jasper Johns, Edward Ruscha und Richard Prince sind die bahnbrechenden Künstler, deren bildgenerative Verfahren und Collagekonzepte Schaesberg paradigmatisch herausarbeitet. Die Collage setzt vorgefundene Bruchstüc ke dieser Welt zusammenhängend ins Werk, wobei die verschiedenen Materialien absichtsvoll nicht nur die Spuren ihrer Herkunft im Bild bewahren, sondern jegliche strikte, sequenzielle Entwicklung eines konsistenten semantischen Bildzusammenhangs verletzt. Die Collage unterminiert systematisch jene Vorstellungen, wie das Werk sich gemäß vorgeblicher ästhetischer Prämissen entfalten soll, um dadurch der Imagination des Betrachters künstlerische Produktionsprozesse zu übertragen.

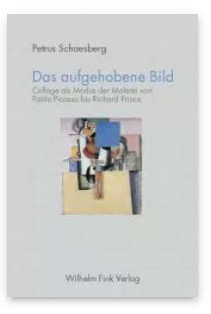

Pages: 220

Seiten, 103 s/w Abb.

Language:

German

Subjects:

General, Art

History

Publisher: Brill |

Fink

E-Book (PDF)

Released online:

25 Jan 2021

ISBN: $978-3-$

8467-4245-7

List price

USD $\$ 63.00$

Paperback

Publication date:

24 Oct 2007

ISBN: $978-3^{-}$

7705-4245-1

List price

USD \$63.00 
For more information see brill.com

Order information: Order online at brill.com +44330 333 0049 | customerservices@brill.com Submission information: brill.com/authors

Titles published by Brill | Fink, Brill | mentis or Brill | Schöningh: +49(o)715413279216| brill@brocom.de 